\title{
CAPISTRANO DE ABREU (1907). O SURGIMENTO DE UM POVO NOVO: O POVO BRASILEIRO
}

\author{
José Carlos Reis \\ Universidade Federal de Minas Gerais
}

\begin{abstract}
RESUMO: O artigo discute inicialmente alguns dados biográficos de Capistrano de Abreu que contribuíram para a posição inovadora que conquistou na historiografia brasileira; examina as suas relações com Varnhagen e o IHGB, a sua hesitação teórico-metodológica entre o positivismo e o historicismo, o seu novo ponto de vista sobre a história brasileira, que se denominou de "redescoberta do Brasil". Resume e analisa a sua obra "Capítulos de História Colonial" procurando apreender todo o seu alcance metodológico e político e conclui com reflexões sobre a temporalidade histórica do Brasil, segundo a sua perspectiva renovadora, que enfatiza a ruptura com a tradição lusitana e a opção pelo futuro brasileiro.

ABSTRACT: The article initially discusses some of Capistrano de Abreu's biographical data that have contributed to the innovative position he has achieved in the Brazilian historiography. It also examines his relationship with Varnhagen and the IHGB, his theoretical-methodological hesitation between positivism and historicism, and his new point of view on the Brazilian history wich was called "rediscovery of Brazil". It summarizes and analyses his work "Capítulos de História Colonial" (Chapters of Colonial History), trying to apprehend its methodological and political attainment and concludes with reflections on the historical temporality of Brazil, according to his innovative perspective, that enphasizes the rupture of the Lusitanian tradition and the option for a Brazilian future.
\end{abstract}

PALAVRAS-CHAVE: Historiografia Brasileira, Capistrano de Abreu, Capítulos de História Colonial, Temporalidade Renovadora, "Redescobrimento" do Brasil.

KEYWORDS: Brazilian Historiography, Capistrano de Abreu, "Capítulos de História Colonial” (Chapters of Colonial History), Innovative Temporality, "Rediscovery” of Brazil. 


\section{Capistrano de Abreu, "Heródoto do Povo Brasileiro"}

João CAPISTRANO DE ABREU nasceu em Maranguape, Ceará, em 1853. Nasceu no sítio de Columinjuba, que seu pai herdara de seu avô, que o havia recebido de presente de um reinól perseguido pelos ódios exacerbados do nativismo local, do qual ele então protegera. Foi assim que a sua família saiu da pobreza e se tornou proprietária de um pequeno pedaço de terra. Ali, Capistrano foi criado com rigidez, severidade e austeridade, em um ambiente marcado pelo trabalho pesado e contínuo e pelo dogmatismo católico. Seu pai, depois de herdar a terra, reconstruiu a casa e se tornou um dos "homens bons", "homens de consideração", da região, pois tinha o suficiente para sustentar a família e gozar de algum prestígio social. Ele pertencia à Guarda Nacional e à burocracia provincial - tinha a patente de major. No sítio, ele plantava cana, algodão, mandioca, feijão, milho. O trabalho era feito por escravos, por agregados e pela própria família. Seu avô e pai eram homens do tipo "amansa-negro": homens de mão pesada e de alma dura. Capistrano nasceu, portanto, em uma "casa grande", modesta, mas abastecida. A casa expressava o espírito místico-escravista dominante: era cheia de imagens de santos, rosários, relíquias, escapulários, terços e orações e um dos seus cômodos era usado como "sala de disciplina", a "sala do tronco", com os instrumentos de suplício para os escravos rebeldes e que, provavelmente, o rebelde Capistrano também conheceu, pois os filhos na sua época eram também "amansados"! Ali reinava o espírito colonizador e inquisidor dos descobridores. O sítio submergia no anonimato da vida sertaneja, cercado por longas distâncias, embora Fortaleza não fosse tão longe. Vivia-se ali uma vida isolada, rotineira, silenciosa, ritmada pela natureza, pelo trabalho e pelas rezas (CÂMARA, 1969).

Foi neste ambiente bem pouco aristocrático que nasceu e viveu até à juventude, Capistrano de Abreu.
Ele era psíquica e fisicamente um autêntico sertanejo, um caboclo matuto, feio, agreste, desagradável: "um desconfiado tapuia transplantado para o meio civilizado", alguém disse. Seus biógrafos descrevem a sua imagem de maneira bem desfavorável - "seboso", mal vestido, sem higiene pessoal, uma figura torta, um olho pendido para o lado, uma cor encardida que o banho só piorava! Para logo desanuviarem a má impressão referindo-se à sua personalidade brilhante e envolvente. Ao chegar, ao ser apresentado a alguém ou ao se apresentar, sua imagem causava desgosto; ao sair, seu espírito deixava encantamento. Foi assim, por exemplo, em seu primeiro encontro com José de Alencar, seu conterrâneo que tinha obtido grande sucesso nacional e a quem ele recorreu para introduzí-lo na Corte. Capistrano não era vaidoso e se silenciava sobre si mesmo. Sabe-se que era próximo e afeiçoado aos escravos e que conhecia muitas canções africanas (CÂMARA, 1969).

Sua formação intelectual, considerando a sua origem modesta e rude, foi outro "milagre". Ele foi sobretudo um autodidata, um leitor apaixonado e desordenado. Foi alfabetizado no próprio sítio e depois estudou em um colégio pobre de Fortaleza - o "Ateneu Cearense", e no Seminário. Como estudante, sempre fracassou em seus exames. Talvez ele tivesse dificuldades psicológicas com a "autoridade", associada ao pai. Seu retorno de Recife, onde passou dois anos preparando-se para entrar na Faculdade de Direito, com o apoio financeiro de seu pai!, foi mais ou menos trágico: ele fracassara em Recife! Entre os 18 e 20 anos, as perspectivas de Capistrano não eram as melhores. Ele ficou no sítio, escrevendo em jornais de Fortaleza, dando aulas em colégios. Ele precisava de um emprego e de um salário para viver. Não era rico e não poderia depender mais do seu pai, sem trabalhar no sítio (CÂMARA,1969).

Ele decidiu, então, ir para a Corte, migrar para o Rio de Janeiro, armado com uma carta de José de Alencar, apresentando-o aos jornais do Rio, e com 
700 mil réis que apurou com a venda de um escravo de sua propriedade, que herdara de seu avô. Em 1875, este "nordestino feioso" desceu para um mundo desconhecido, incerto, "sozinho, sozinho". Ele chegou ao Rio com 21 anos. Apesar da sua resistência ao bacharelismo, chegou com uma boa bagagem intelectual: lia francês e inglês, conhecia filosofia, literatura, história e geografia. Assim dizem seus biógrafos mais exaltados. E exageram: ele lia até sueco (CÂMARA, 1969)! Na Corte, ele precisava de um emprego. Trabalhou na Livraria Garnier, foi professor no Colégio Aquino, "onde tinha casa e comida", escreveu vários artigos em jornais, passou em um concurso para o preenchimento de uma vaga na Biblioteca Nacional, um emprego público, estável e seguro, a âncora que ele precisava para fixar-se na Corte. Em 1883, ele fez o famoso concurso para ser professor de "Corografia e História do Brasil" do Colégio Pedro II. Passou, ocupou a vaga, mas não ficará muito tempo, pois sairá em 1899. Sua cátedra foi extinta - "História do Brasil"! - que foi incluída na "História Universal”. Enquanto ensinou, sem carisma, teve alunos e nunca discípulos. Ao sair do Colégio, sentiu-se aliviado: livrara-se de "alunos ignorantes e desatentos". Contudo, a razão da sua saída do Colégio Pedro II permanece ainda mal explicada. Alguma razão política? Chacon afirma que Capistrano e O.Lima, acusados de germanofilia quando da Primeira Guerra Mundial, teriam sofrido perseguições (CHACON, 1993, p.92). Mas, a sua saída do Pedro II foi em 1899 , bem antes. Qual foi a verdadeira razão? Foi somente uma simples "reforma do ensino" que dissolvia uma cadeira de "História do Brasil"!? Capistrano morreu em 1927, aos 64 anos (CÂMARA, 1969).

Sua biografia interessa muito, quando se conhece o lugar inovador que ele teve na historiografia brasileira. A biografia escrita por J.S. Câmara, que utilizamos até aqui, parece-nos recomendável, apesar de um excesso, talvez, de "empatia", embora compreensível. Quem é, afinal, o autor de Capítulos de Histó- ria Colonial? Num mundo social marcado profundamente pela bipolarização senhor-escravo, ele não era nem uma coisa e nem outra. Sua família era pequena proprietária de terra e produzia para o seu próprio sustento. A maneira como conseguiu essa terra também é curiosa, casualmente, um "presente de reinól”! A produção não era destinada ao mercado internacional, mas era feita também com mão de obra escrava e de agregados, que trabalhavam lado a lado com os membros da família proprietária. Era um mundo social "brasileiro", isto é, voltado para dentro, sem vínculos externos diretos. A subsistência era retirada da terra, parca e modesta, à custa de um trabalho contínuo e braçal, quase sem equipamentos. $\mathrm{O}$ horizonte pessoal de Capistrano era prosseguir esta vida paterna e familiar, horizonte que ele recusou, contra o qual se rebelou, mas ao qual tinha pouca coisa ou quase nada para substituir. Refugiou-se, então, talvez, na leitura, evadiu-se, o jovem Capistrano. Criou um mundo de palavras, frases, citações confusas e em outras línguas (apelando até para o sueco!), buscando "diferenciar-se" do seu mundo, do seu passado, buscando o reconhecimento intelectual, o prestígio de homem de letras, devorador de livros, mas pouco disciplinado para enfrentar exames.

No Rio, quando não tinha mais terra e nem era mais proprietário de escravos, passado que rejeitara, ele só tinha a sua força física e seus olhos leitores como instrumento de trabalho. Ali, ele precisava sobreviver e mostrar o seu valor. Tendo rompido com aquele passado, ele rompeu também com o futuro previsível que ele prometia; agora, ele enfrentava um futuro desconhecido, que ele teria de produzir com os seus próprios recursos. Capistrano preferiu a mudança e a sua instabilidade à continuidade familiar e nordestina. Sua história pessoal se parece com a interpretação que construiu do Brasil: rebeldia e recusa do passado, opção por um futuro novo; mas qual?! O “Necrológio de Varnhagen”, escrito em 1778, três anos depois da sua chegada ao Rio, talvez tenha sido 
o seu grande trampolim para o futuro que ele queria realizar: repercutiu tão intensamente, dizem, que até o insuperável Machado de Assis evitou publicar o seu! Capistrano começou então a sentir o gosto da vitória e do sucesso, depois de experimentar fracassos sucessivos no Nordeste. Seu horizonte novo se abria e se ensolarava na Corte (CÂMARA, 1969).

Ele viverá até 1927 com os seus únicos recursos: postos públicos e a sua escrita concisa, precisa e inovadora. Entretanto, a sua obra é pequena e constituída de textos curtos. Ele viverá na verdade mais da sua renda de funcionário público, bibliotecário e professor, do que dos seus escritos, que ele próprio parecia não apreciar muito. Quando terminados, ele dizia sentir por eles "alívio e nojo" (CÂMARA, 1969). Talvez, este seja também o sentimento de um operário diante da sua obra terminada: "alívio", pois deu conta de fazê-la e já podia ir para casa com o salário no bolso; "nojo", pois a produzira sob pressão, dominado pela necessidade. Como um operário, um migrante nordestino, Capistrano é um homem humilde, discreto, tímido, avesso a títulos e glórias e indiferente à audácia e perícia do trabalho que realiza.

\section{Varnhagen e Capistrano}

Quando ele nasceu, em 1853, Varnhagen começava a publicar a sua História Geral do Brasil. Capistrano será o seu leitor mais atento e crítico. Será em relação a Varnhagen que ele fará a sua grande inovação na interpretação do Brasil. Esta inovação se explica não só em termos da sua origem social, que é totalmente diversa da de Varnhagen, mas também em razão da nova época intelectual vivida pelo Brasil nos anos posteriores a 1870. O desfecho da Guerra francoprussiana abalara o prestígio da cultura francesa e os intelectuais brasileiros se abriram às influências inglesa e alemã: Spencer, Darwin, Buckle, Ranke, Ratzel. Os franceses ainda influenciavam: Comte, Taine, Tarde, Renan, G. Le Bon. Pós-1870, o ambi- ente intelectual brasileiro era mais complexo, refletindo também a maior complexidade da vida brasileira, que se inquietava após o fim da Guerra do Paraguai. Varnhagen escrevera quando a monarquia se consolidava nos anos 1850; Capistrano construirá a sua interpretação do Brasil quando a Monarquia estava abalada, em xeque, assim como a escravidão, e se buscavam novas bases econômicas, sociais, políticas e mentais para o Brasil (WEHLING, 1994).

Os intelectuais brasileiros do final do século XIX começaram a perceber a distância entre a realidade brasileira e o pensamento que eles próprios produziam. Silvio Romero criticava o ambiente intelectual brasileiro, vazio e banal, e aspirava ter contato com o verdadeiro Brasil. Há um esforço de todos para encarar de forma nova o passado brasileiro. Eles têm, agora, uma preocupação "cientificista". Comte, Buckle, Darwin, Spencer serão as referências intelectuais predominantes (ORTIZ, 1985). A preocupação cientificista de Capistrano era a de toda uma nova geração. No pós-Guerra do Paraguai, esta geração quer reinterpretar a história brasileira privilegiando não mais o Estado Imperial, como Varnhagen, mas o povo e a sua formação étnica. A formação intelectual de Capistrano se deu neste ambiente determinista, cientificista, até racista. Discutia-se, então, o positivismo, o determinismo climático, o determinismo biológico, o spencerismo, o comtismo, o darwinismo, as teorias raciais. Pensava-se que a sociedade poderia ser estudada com a mesma objetividade com que se estudava a natureza, pois também submetida a leis gerais de desenvolvimento. A história seria como o universo: um mecanismo auto-regulado, submetido a leis, passível de um conhecimento objetivo. A ciência passava de método a visão de mundo, desvalorizando as verdades trazidas pela tradição, pela religião, pela filosofia. Euclides da Cunha, O. Vianna, Silvio Romero, Tobias Barreto, enfim, a geração de Capistrano de Abreu, discutia darwinismo social, luta pela vida, seleção das espécies e defendia um co- 
nhecimento anti-metafísico, empírico, histórico (CHACON 1977; WEHLING, 1994).

No entanto, havia posições heterodoxas. Tobias Barreto, por exemplo, opunha-se ao cientificismo predominante opondo-lhe o historicismo neokantista alemão. Quando se trata do homem e da sociedade, ele sustentava, há sempre um "resto" que a mecânica não explica; aliás, este "resto" mecanicamente inexplicável é quase tudo quando se trata do homem. O que há, então, é um "todo inexplicável”. Naquele ambiente spenceriano, Tobias Barreto já era um culturalista, um pioneiro historicista. Não há leis para a história humana.

O pensamento brasileiro do final do século XIX, portanto, estava dividido. A "Escola de Recife" mantinha a distinção entre natureza e cultura, resistia ao cientificismo sociológico; este dominou a Escola Politécnica do Rio de Janeiro, a Escola de Minas de Ouro Preto, o Colégio Pedro II, a Escola Normal, O Colégio e Escola Militares, a Escola Naval, as Faculdades de Medicina e Direito, que formavam os profissionais liberais, políticos, intelectuais, empresários, impregnados de Comte, Spencer e Darwin. (CHACON, 1977; WEHLING, 1994).

\section{Capistrano: positivista ou rankiano?}

O pensamento de Capistrano revela esta divisão e confusão da discussão intelectual no Brasil no final do século XIX. Qual era a sua tendência: mais positivista ou mais historicista? P. M. Campos afirma que Taine, Buckle e Comte foram importantes na sua formação. Chacon o considera um dos numerosos adeptos de Spencer da época. (CHACON, 1977) Entretanto, se a "Escola de Recife" era mais historicista, fica um pouco difícil perceber a sua formação positivista em Recife. Talvez, quando foi para o Rio de Janeiro ele tenha tido um maior contato com os autores positivistas ingleses e franceses no Colégio Pedro II e ali, também, tenha sofrido a doutrinação dos deba- tes positivistas. Os analistas de Capistrano arrolados abaixo dizem mais ou menos o mesmo (CAMPOS, 1983).

Para R. Benzaquen, ele sempre se interessou teoricamente pelos sociólogos franceses, ingleses e alemães. A perspectiva sociológica influenciou-o e ele lamenta que Varnhagen não a tivesse empregado ao não procurar leis na história do Brasil. No "Necrológio...", em 1878, e já no Rio de Janeiro, ele reafirmou a sua crença na possibilidade de se encontrar leis para a história do Brasil. Ele esperava um Spencer ou um Buckle da história do Brasil. A sua obra é um ponto de referência da recepção da concepção moderna de história, com o seu ideal objetivista de verdade, apoiada em documentos inéditos, testemunhas oculares, autores identificados das fontes. Para ele, o distanciamento do historiador deve se dar quando ele manipula as fontes; em um segundo momento, quando ele as interpreta, o quadro teórico das ciências sociais orientará a pesquisa com suas leis e teorias (ARAÚJO, 1988).

P.M. Campos afirma que ele se interessou por tudo o que saiu da Europa, em particular pela bibliografia alemã. Interessava-se por economia política, história da América e de Portugal, psicologia, que ele considerava indispensável ao historiador, e geografia. A influência alemã levou-o ao estudo rigoroso dos documentos - Capistrano quer também narrar o que de fato aconteceu. Ele defende o realismo histórico alemão. Entretanto, ele esteve embebido em influências diversas, não somente alemãs. Aquelas características da sua obra - estrita observação das fontes e pesquisa das relações do homem com o meio geográfico - se partiram da Alemanha, já pertenciam a todo o Ocidente. Sua obra, afirma Campos, não permite uma avaliação do grau de influências recebidas. Foram publicadas como artigos, esparsamente, e seus livros não possuem prefácios. Só em sua correspondência se pode conhecer as suas leituras. Sua correspondência, aliás, é um valioso material para a história das idéias no Brasil do final do século XIX e início do $\mathrm{XX}$. Nelas, Campos não percebeu nem preconceito e 
nem exclusivismo cultural. Capistrano nunca teria proposto uma explicação unilateral da história, mas sempre percebeu a interdependência das diversas instâncias sociais (CAMPOS, 1983).

Para A. Canabrava, tal como em Varnhagen, a exegese documental, que ocupou muito do seu tempo, parece inspirar-se em Ranke. Os dois se encontram na preocupação fundamental pelo documento, pela busca da autenticidade, pela verdade das fontes, pela esforço de análise objetiva. Entretanto, diferente de Varnhagen, que não se interessou por teoria, Capistrano, que nunca saiu do Brasil, tinha grande interesse pelas correntes do pensamento europeu no campo das ciências sociais. Canabrava afirma ter encontrado em sua correspondência muitas referências a diversos teóricos europeus: Taine, Buckle, Comte, Ratzel, Spencer, Sombart, Ranke. Capistrano lia estudos empíricos e ensaios teóricos em assuntos variados. Interessou-se tanto pela história do clima e da Rússia como pela história do Brasil. Ele foi um dos pioneiros da geografia humana. Entretanto, conclui Canabrava, ele era teoricamente confuso: não dominava vários conceitos que ao seu tempo as ciências sociais tinham formulado. Faltou-lhe uma problemática consistente, que desse ao seu pensamento uma diretriz fundamental de interpretação; faltou-lhe, enfim, "unidade teórica". Ele apenas aflorou os grandes temas das ciências sociais, sem dominá-los (CANABRAVA, 1971).

Para Wehling, a influência cientificista é determinante na obra de Capistrano entre 1874 e 1880 . A sua biografia intelectual começa no Ceará, no círculo positivista formado por Rocha Lima, Araripe Jr., Tomás Pompeu Filho entre outros. O grupo atuava no sentido da educação do "proletariado", na linha comtista. Escreviam em francês, faziam conferências na Escola Popular que fundaram. Capistrano escrevia artigos e pronunciava conferências sobre as influências positivistas de Spencer, Buckle, Comte e Taine. Entre 1874 e 1883, enfim, Capistrano rezava a cartilha cientificista: unidade do real, busca de leis deterministas, evolucionismo, cognoscibilidade e objetividade do conhecimento social, unidade epistemológica das ciências sociais (WEHLING, 1994).

Entretanto, Wehling considera que este interesse pelas idéias positivistas se restringiu a uma fase inicial de sua formação. Depois, com o aprendizado do alemão, ele teria passado do positivismo ao realismo histórico rankiano. Ele optou pela pesquisa documental e pelo método crítico alemão que, aliás, ainda hoje é chamado impropriamente de "positivista", por causa da influência da Escola dos Annales (REIS, 1996). Houve uma reviravolta em seu pensamento, cuja data não é fixável. A influência alemã o retirou do positivismo e o levou à hermenêutica. Mas, não foram leituras teóricas que o retiraram do cientificismo, como quer J.H.Rodrigues, afirma Wehling. Para este, foi o estudo de documentos, o primado do objeto, que converteu Capistrano do cientificismo à ciência. A rebeldia das fontes ante os esquemas interpretativos fez com que ele os restringisse a hipóteses de trabalho. O real era reconstruído a partir de sugestões científicas que conduziam ao levantamento dos fatos. A composição e interpretação desses fatos obedecem à lógica da situação histórica. Capistrano tinha pouco interesse por problemas teóricos e metodológicos da história. Na sua fase científica, ele utilizou leituras européias como sugestões temáticas, como hipóteses de trabalho. O seu interesse teórico na fase cientificista foi sem conseqüências para a pesquisa que realizou e repercutiu na fase posterior. Portanto, para Wehling, a resposta à questão sobre a orientação teórica de Capistrano é clara: ele passou por duas fases: uma primeira cientificista, franco-inglesa, e outra científica, alemã, rankiana. As suas grandes obras são da segunda fase.

Rodrigues considera que Capistrano fez uma reviravolta na historiografia brasileira por sua posição teórica atualizada, seu conhecimento incomum dos fatos, seu novo ideal de história do Brasil. Os seus 
artigos de 1879 revelaram a influência positivista, não só na investigação como na interpretação dos fatos da história do Brasil. Ele era amigo de Teixeira Mendes e Miguel Lemos, apóstolos comtistas no Rio de Janeiro. Mas, o convívio com autores alemães fazem-no ir à procura das realidades, segundo ideais não positivistas. Em suas obras mais importantes ele não deduz e generaliza tão facilmente. Rodrigues precede Wehling em sua leitura da "reviravolta" no pensamento de Capistrano. Sob as influências de Ranke, Niebhur e Humboldt, ele passará a dar ênfase aos documentos, à sua crítica e interpretação, sem buscar leis, mas a “compreensão". Entretanto, apesar da influência alemã, sobrevive uma certa influência de Spencer. Mas, o positivismo, ele passará a considerá-lo como uma "camisa de força" e a influência alemã será cada vez maior: Ranke e Ratzel. Ele recusa os determinismos geográfico, climático e racial e o evolucionismo. Historicista, ele percebe que a vida em eu mistério pede um tratamento diferenciado da natureza. Seus estudos sobre a história íntima, festejos, família, procurando a diferença, a individualidade, as significações, o afastam do que é típico, regular, constante. A ação humana não se submete a regras e leis gerais (RODRIGUES, 1963 e 1965).

Deixando o positivismo, ele passou a se interessar pelo método crítico, que mais uma vez, desde a Escola dos Annales, é visto inadequadamente como a marca da "história positivista" (REIS, 1996). Mesmo se Spencer é forte, e ele o será até os anos 30, até G. Freyre, a influência alemã é que fundamentará as obras mais relevantes de Capistrano. Historicista e não positivista, o segundo Capistrano quer captar a interioridade dos testemunhos. A história não é só fato, é emoção, sentimento e pensamento dos que viveram. Mas, se apreciava a metodologia de Ranke, ele não seria capaz de se apagar para narrar os fatos tal como se passaram. Rodrigues o considera a mais lúcida consciência da história do Brasil: ele recriou o passado brasileiro, enfrentando os seus males, su- perando-os, reabrindo o futuro do Brasil (RODRIGUES, 1963 e 1965).

Odália o vê como exemplar de uma interpretação do Brasil que privilegia o indígena, por um lado, e, por outro, ele é mais um historiador brasileiro que importa teorias européias e se dilacera para atender a essas teorias que condenavam o Brasil a um triste destino, para que este destino não se realizasse. Por um ato de vontade e de contorcionismo teórico negase o destino pré-fixado pelos cientificistas europeus, que afirmam a impossibilidade de uma nação civilizada nos trópicos e ainda por cima miscigenada (ODÁLIA, 1976). Capistrano, no entanto, será diferente da sua geração. Ele reabrirá o futuro do Brasil, vencerá o pessimismo existente entre os intelectuais brasileiros que olhavam o Brasil com as teorias deterministas européias e nele não viam o que elas valorizavam, mesmo se ele também, em uma primeira fase, impregnou-se com tais teorias e tenha feito também algum contorcionismo teórico. Finalmente, ele optou pela teoria também européia que valoriza a singularidade, a historicidade de cada povo e formulou uma nova interpretação do Brasil que enfatizará o tempo histórico especificamente brasileiro.

\section{A "Redescoberta do Brasil"}

Capistrano será um dos iniciadores da corrente do pensamento histórico brasileiro que "redescobrirá o Brasil", valorizando o seu povo, as suas lutas, os seus costumes, a miscigenação, o clima tropical e a natureza brasileira. Ele atribuirá a este povo a condição de sujeito da sua própria história, que não deveria vir mais nem de cima e nem de fora, mas dele próprio. O futuro do Brasil torna-se tarefa do povo brasileiro e, para melhor vislumbrá-lo, Capistrano recupera o passado deste povo em suas lutas e vitórias. Capistrano foi pioneiro na procura das identidades do povo brasileiro, contra o português e o Estado Imperial e as elites luso-brasileiras. 
Seu papel na história do Brasil, a significação da sua obra, os caminhos novos que apontou, os seus ideais e conceitos e contribuição à história colonial podem ser avaliados nos Capítulos de História Colonial. Ele não fez uma história exclusivamente políticoadministrativa ou biográfica, mas procurou apreender a vida humana na multilateralidade de seus aspectos fundamentais. Sua visão da história não atribui predominância de um fator sobre outros; ele a vê como um conjunto complexo de fenômenos humanos. Para ele, como historicista, o historiador deve recriar a vida integralmente, realizar uma compreensão total e criadora do curso histórico. O conceito de "cultura" substitui o de "raça" e neste aspecto ele é precursor de G. Freyre, assim como de S.B. de Holanda. Ele valoriza a presença indígena e pensou um Brasil mais mameluco do que mulato, mais sertanejo do que litorâneo. Nos Capítulos de História Colonial, aparecem os caminhos que levam ao sertão e o próprio sertão brasileiro. Adentrando pelo Brasil, o colonizador se alterou e se tornou uma personalidade distintamente brasileira. Vivendo no interior do Brasil, ilhado e sem vínculos contínuos com o litoral, convivendo com os indígenas e a natureza brasileira, foi-se constituindo um "homem novo", até então inexistente no mundo: a história universal ganhava um novo personagem, o "brasileiro". Mas, enfatizando o sertanejo, ele não perde de vista o nacional, a unidade brasileira em suas diferenças regionais. Ele não faz ainda uma história econômico-social, mas já trata do homem comum, sobretudo nos capítulos finais do seu Capítulos de História Colonial. Seu grande tema foi o da ocupação do território, a sua conquista pelo "novo povo brasileiro".

O seu Capítulos de História Colonial, publicado em 1907, é uma "nova história" do Brasil, embora muito parecida com Capistrano fisicamente: modesta, magra, quase silenciosa. Mas, ao mesmo tempo, extremamante eloqüente. É uma síntese que reúne muitos fatos esparsos, encadeados em uma perspectiva inovadora. Varnhagen escreveu uma obra de sín- tese também parecida com ele, isto é, em cinco volumes! Mas, como "síntese", isto é, como apreensão da totalidade, como integração da multiplicidade, sua obra é menos reveladora do que a de Capistrano. Este escreveu uma obra magra, "a grandes traços e largas malhas", contra os "quadros de ferro" de Varnhagen. Seu interlocutor era Varnhagen, a quem ele admirava e se opunha. Capistrano escreveu o seu livro em um ano. Seus analistas o consideram uma pequena obraprima da historiografia brasileira, por sua linguagem simples, por sua compreensão intuitiva da história do Brasil em seus fatos e em seu conjunto, pela documentação segura e numerosa, "por seu interesse pelo povo durante séculos capado e recapado, sangrado e ressangrado", como afirma Rodrigues. Ele pretendeu ensinar ao povo brasileiro o seu segredo, ensinar-lhe a sua "história pátria", numa época em que a história nacional era desprezada. A sua cadeira de "História do Brasil" foi até extinta e ele posto em disponibilidade! Enquanto a história de Varnhagen era uma conversa entre eruditos, Capistrano divulgará com simplicidade o conhecimento da história do Brasil, mais econômico-social do que política, liberta de datas, nomes e eventos oficiais.

O “Capítulos..." é uma história da luta dos brasileiros pela independência, contra vice-reis e governadores que os sufocavam. Capistrano foi um homem de síntese, uma síntese precedida de longas investigações. Sua síntese toca em todos os pontos mais relevantes da vida brasileira, é a mais viva e condensada história colonial do Brasil. Tendo como personagem central o povo, o indígena ganha um papel importante na formação do Brasil. Para Capistrano, o que houve de diverso entre o brasileiro e o europeu, deveu-se ao clima e ao indígena. $\mathrm{O}$ brasileiro é o europeu que sofreu um processo de diferenciação: o clima e a miscigenação com o índio. Interessa-lhe conhecer o que este povo sente e aspira. Ele faz uma história social e econômica do povo, sua vida, alimentação, tipos étnicos, condições geográficas, os caminhos, economi- 
as, povoamentos, modos de viver, as formas psicológicas, profissões, divertimentos, costumes, crenças, diferenças sociais, o comércio, a vida urbana e rural... Sobretudo, ele identifica este povo, que no período colonial e mesmo imperial não sabe bem o que é e o que faz e deveria fazer. Ele revela o processo de constituição da diferença entre o projeto colonizador e o novo interesse e sentimento que se formara gradualmente, o interesse e sentimento "brasileiros". Varnhagen fez o elogio da vitória dos portugueses, defendeu os interesses e os sentimentos lusitanos no Brasil e não via com bons olhos a diferença que volta e meia explodia entre estes valores e poder europeus e os autóctones. Capistrano escreverá uma "outra história do Brasil": anti-portuguesa, anti-reinól, anti-européia, anti-Estado Imperial, anti-político-administrativa. Ele ecoará as vozes de Antonil e dos rebeldes de todo o período colonial. "Redescobrindo o Brasil", Capistrano fará o elogio da "rebelião brasileira".

\section{A Obra: "Capítulos de História Colonial”}

Capítulos de História Colonial começa com dois capítulos "estáticos", isto é, capítulos que apenas oferecem os dados da história que ele vai narrar e interpretar. No primeiro capítulo, intitulado "Antecedentes Indígenas", Capistrano realiza uma descrição geográfica do Brasil, o palco sobre o qual se desenrolará a história que ele narrará a partir do terceiro capítulo. Ele começa pelos dados iniciais, os mais elementares. Inicialmente, é preciso situar o Brasil: onde fica, limites a leste, oeste, norte e sul, as suas dimensões. Ele faz considerações sobre o relevo, os acidentes e singularidades geográficas, realizando uma espécie de mapeamento do território. Como alguém que olha em volta identificando onde está e o que possui. Em sua "corografia do Brasil", aparecem as serras, baías, baixadas, rios, climas, florestas, fauna, com uma avaliação sobre cada serra, cada rio, cada floresta, cada animal...
Habitando este território, há o indígena, que é também descrito em seus hábitos, comportamentos, atividades, técnicas, guerras, vida sexual, trabalho, educação, religiosidade, artes, lendas, língua. E também com avaliações: ele domestica somente animais de "estimação" e não para o uso na vida cotidiana; possui uma agricultura incipiente; dependem do trabalho das mulheres, que é considerada inferior ao homem; são nômades; antropófagos; têm os sentidos apurados; cultuam os antepassados; têm uma língua comum e vivem, infelizmente, dispersos porque o meio dispensa e impede a cooperação. Portanto, a natureza e os índios são os temas dos "Antecedentes Indígenas", o primeiro capítulo da história colonial brasileira. Capistrano faz uma descrição geográfica do Brasil e uma apresentação dos seus primitivos moradores. Estes são os dados iniciais da história do Brasil, os que foram encontrados aqui. A estes dois dados, ele acrescentará outros dois que não eram daqui, mas vieram parar aqui: o europeu e o africano. A estes dois ele denominará de "Elementos Exóticos", os "alienígenas", que serão os temas do segundo capítulo.

Nestes dois primeiros capítulos, quando são apresentados os "dados iniciais da história do Brasil" - o palco natural e os personagens que atuarão sobre ele, indígenas e alienígenas - Capistrano se aproxima de Varnhagen na sua descrição do primeiro Brasil; e Varnhagen é até mais informativo, minucioso. Diferencia-se de Varnhagen na perspectiva que terá sobre tais dados. Para Capistrano, "alienígenas", "exóticos" são os europeus e africanos e não o indígena e a terra do Brasil. Para vê-los assim, ele se coloca do ponto de vista do indígena e da terra do Brasil, que vêm chegar novos e desconhecidos elementos. Ele olha da praia para o Oceano cheio de caravelas, enquanto Varnhagen olhava da caravela de Cabral para a praia, e via uma terra exótica povoada por alienígenas. No segundo capítulo, portanto, ele faz ainda uma "descrição estática", isto é, neles próprios, dos "fatores exóticos" que desembarcaram no Brasil. 
Ele descreve então a situação de Portugal no século XVI, a sua transição conciliada da Idade Média à Moderna: o poder da Igreja mais limitado, mas ainda influente; as relações entre o Estado português e Igreja, seus atritos e proteções recíprocas. A sociedade secular emergente luta para limitar os poderes da sociedade religiosa ainda dominante. Ele descreve a hierarquia social portuguesa do XVI: o Rei, a quem tudo pertencia e que tudo podia; abaixo dele, a nobreza, com seu poder agora limitado pela centralização do poder real, e o clero; abaixo, o povo, a grande massa, sem direitos pessoais, sem grande importância; abaixo ainda, os servos, escravos, que podiam passar à categoria superior, pois as classes não eram castas. A nobreza, o clero e o povo constituíam as "Cortes", que o Rei absoluto desdenhava e só convocava quando precisava aumentar os impostos. A população portuguesa em 1527 era de mais ou menos 122.112 almas. E ele formula a questão que a todos espanta: como esse pessoal exíguo, que nem enchia Portugal direito, pode povoar o mundo?! Capistrano antecipa-se a G. Freyre e a S.B. de Holanda na caracterização do "caráter português": fragueiro, abstêmio, imaginação ardente, místico, independente, antidisciplinar, não convencional, de fala livre, sem eufemismos, o coração duro. Matava por quase nada e cuidava pessoalmente da defesa da sua propriedade. Suportava melhor a dor física do que a dor moral; o ser fisicamente forte era valorizado. E antecipa também aqueles dois autores dos anos 1930 na resposta àquela questão: por serem assim, só este povo pode ser capaz de se misturar com outras etnias e culturas. O português é o primeiro elemento exótico, o primeiro imigrante, o invasor conquistador e colonizador.

O segundo elemento exótico é o negro. Ao português estranho ao continente juntou-se o negro, também alienígena. A importação deles começou cedo. Eram robustos e resistentes e substituíram o índio no trabalho rude. Tinham uma índole carinhosa, sobretudo os domésticos. O negro trouxe alegria ao lado do português taciturno e sorumbático. Suas danças lascivas, suas feitiçarias e crenças propagaram-se entre os brancos. As mulatas tornaram-se rainhas. Em relação ao negro, Capistrano é menos "estático" - ele não se refere a eles somente no século XVI, ao estado em que se encontravam quando vieram. Ele não se refere aos negros na África, como aos portugueses em Portugal. Capistrano fala deles, já no segundo capítulo, indo do século XVI até o século XIX - 1850 e a abolição, muito brevemente. Mas o espírito é o mesmo, isto é, o de uma "apresentação" do personagem negro e do papel que ele terá na história do Brasil. Talvez seja menos "estático" em sua apresentação do negro porque será ao longo da obra muito reticente, quase silencioso sobre ele. Já na apresentação Capistrano esgotou tudo o que queria dizer sobre o negro. Este entrará em sua história em rápidos momentos, sem qualquer peso histórico. Capistrano vai se interessar mais pelas relações entre brancos e índios e pelo seu mestiço, o mameluco sertanejo.

Finalmente, no terceiro capítulo, intitulado "Os Descobridores", estes elementos anteriormente estáticos se animam: o português chega àquela geografia e encontra aquele índio. Por que os portugueses vieram parar no Brasil? Esta é a primeira questão posta por aquele que quer compreender a história que se desenrolou no Brasil. Os portugueses vieram porque: a posição geográfica de Portugal destinava-os à vida marítima; desejavam encontrar o imperador-sacerdote Preste-João, para tê-lo como aliado na luta contra os infiéis; as especiarias orientais davam altos lucros no mercado europeu. Com estas motivações - geográfica, religiosa, militar e comercial - os portugueses atiraram-se sobre a África procurando um caminho marítimo para as Índias, que os levasse a obterem os produtos diretamente, evitando as rotas comerciais controladas pelos inimigos infiéis. As teorias cosmográficas eram limitadas na época. O périplo africano era tido como impossível e a via ocidental também. Contra as autoridades e evidências, portugueses e 
espanhóis tentaram a via meridional africana e a via ocidental. Os portugueses chegaram às Índias e ao Brasil e os espanhóis à América. Os espanhóis, aliás, estiveram no Brasil antes dos portugueses, mas sua presença aqui foi sem conseqüências.

Interessa-nos, portanto, afirma Capistrano, Cabral e os portugueses, já que o Brasil se tornou lusitano. A presença espanhola inicial foi irrelevante para a história do Brasil. Ele então descreverá varnhagenianamente a aventura de Cabral: partiu em 1500, com treze caravelas, chegou no dia 21 de abril. Foram dias e espetáculos extraordinários. Celebraram uma missa, hastearam uma cruz. Caminha escreveu a sua famosa carta. Vieram, depois, novas expedições para explorar a Ilha de Vera Cruz. Os naturais aparecem sob nova luz: selvagens, rancorosos, antropófagos, material mais de escravatura do que de conversão! Capistrano põe-se no lugar do português que chega, procura sentir suas expectativas e medos. Mas, ele não permanecerá nesse lugar - ele o ocupará às vezes para melhor compreender a sua ação. Com a exploração do paubrasil, a terra passou a se chamar Brasil. Havia outros nomes concorrentes: "Terra dos Papagaios", "Ilha de Vera Cruz", "Terra de Santa Cruz". O comércio de pau-brasil levou à fundação de feitorias. O Pacífico foi "descoberto", isto é, "visto pela primeira vez pelo europeu", em 1520. E Colombo chegava finalmente às Índias. Neste primeiro Brasil, o que havia era o pau homônimo, papagaios, escravos e mestiçagem. As índias queriam a mestiçagem, pois desejavam filhos da "raça superior". Só o pai conta, para a descendência indígena. E os presentes dos brancos, e talvez esta seja a verdadeira razão do interesse das índias pelos brancos, eram irresistíveis: anzóis, pentes, facas, tesouras, espelhos. Quanto aos portugueses, eles não tinham outra escolha a não ser a índia, pois brancas não havia. Os primeiros colonos do Brasil eram degredados, desertores, náufragos. Uns se tornaram índios, outros os combateram, outros se indianizaram sem perderem a identidade européia.
Assim Capistrano descreve a chegada dos portugueses ao Brasil: à Varnhagen, "fotografou" os fatos mais miúdos, descrevendo-os detalhadamente. Junto com eles, outros personagens exóticos e alienígenas chegaram: franceses, holandeses, ingleses, que ameaçarão a "descoberta portuguesa". Portugal argumentava que a terra era sua por decisão papal. Entretanto, a presença dos outros alienígenas representava uma concorrência séria: eles vendiam os mesmos produtos e mais baratos na Europa e estimulavam os índios contra os portugueses. Os tupinambás se aliaram aos franceses. Durante décadas não se soube se o Brasil pertenceria aos portugueses ou aos franceses. As armadas guarda-costas eram caras e ineficientes. Conversar, dialogar, embaixadas e tratados não adiantavam. Só restava uma solução para afastar os outros invasores: ocupar a terra. Em 1531, Martim Afonso de Sousa veio fazer duas coisas: povoar e guardar o litoral. Fundou a primeira cidade, São Vicente, e uma segunda, Piratininga.

Pressionados, os portugueses tiveram de agir rapidamente: criaram um sistema monumental de capitanias hereditárias, estimularam a emigração para o Brasil. A alta nobreza não aceitou o empreendimento, que ficou com a pequena nobreza. O Rei cedeu parte do seu poder aos donatários. Estes ficaram fortalecidos para enfrentarem o estrangeiro e o sesmeiro. A história do Brasil no século XVI se passou em trechos exíguos de Pernambuco, Bahia, São Paulo, bem próximos do litoral. A energia dos donatários continha a turbulência dos colonos. Surgiram canaviais e engenhos, lavouras de mantimentos, pescava-se fartamente na costa. Entretanto, se o sistema de capitanias hereditárias protegia a costa, ocupava e povoava com a miscigenação, ele levou alguns donatários à falência. Além disso, cada capitania era soberana, estrangeira uma em relação à outra. Não havia uma ação coletiva, mas concorrência. Os crimes cometidos em uma capitania não eram punidos em outra. Havia uma anarquia intercapitanial, além da anarquia intracapi- 
tanial. O Rei decidiu criar uma Capitania Real e enviou um representante seu. Estabeleceu-se um governo central para o Brasil, forte o bastante para garantir a ordem interna, em 1549. Vieram os primeiros jesuítas, que depois dariam tanto trabalho. A preocupação já no século XVI era com a unidade da colônia, que o sistema de capitanias ameaçava. O regime de Capitanias e o Governo Geral significaram o início da vitória portuguesa. O Brasil seria português, tudo indicava. Entre 1580 e 1640, o Trono português esteve sob o domínio espanhol, por razões dinásticas. Mas, o domínio espanhol não comprometeu a vitória portuguesa no Brasil. Pelo contrário, favoreceu-a. Com o apoio espanhol, os portugueses ocuparam a Amazônia e expulsaram franceses e holandeses do norte e nordeste do Brasil.

Capistrano, então, faz um primeiro balanço do resultado dessa história, chegando agora ao final do XVI. Nesta época, o povo era constituído por três raças vindas de continentes diferentes e seus respectivos mestiços. Eram desafetos. Tanto entre eles quanto entre os mestiços internamente. O negro ladino e crioulo desprezava o boçal, o índio catequizado, o nu, o reinól, o mazombo. Forças dissolventes, centrífugas, dominavam a sociedade colonial do século XVI. Só havia a percepção da diferença e não da unidade. Esta era garantida à força pelos portugueses que ocupavam, povoavam, miscigenavam e expulsavam. Os índios temiam e ao mesmo tempo eram fascinados pelos portugueses, pelos seus equipamentos de caça, pesca, guerra, vestuário e objetos coloridos e brilhantes. Mas, faziam-lhe a guerra. Os negros, dominados, oprimidos, escravizados e estrangeiros, viviam sob a hostilidade constante do português. Hostilidade, talvez, atenuada pela solidão do branco, que o forçava a aproximar-se de índias e negras. Os índios fugiam para a floresta, os negros chegavam algemados e humilhados. Os brancos, armados de espadas e terços, humilhavam, ofendiam, estupravam, escravizavam e exterminavam índios, negros e mestiços de uns e outros e expulsavam brancos de outras nacionalidades e religiões. Poderia sair uma "nação" daí? Haveria alguma possibilidade de "unificação de interesses e sentimentos" tão diferentes, de mentalidades separadas por um abismo, abismo aprofundado progressivamente pela escravidão e pela guerra? Capistrano oferece uma resposta otimista: devagar, ele afirma, ao longo do século XVII, essa dispersão geral foi cedendo lugar a uma possível "união brasileira".

Para a constituição da unidade do "povo brasileiro", as guerras holandesas, entre 1624 e 1654, foram decisivas. Depois delas, a história universal possuía um novo personagem, um "povo novo". Os holandeses foram obrigados a invadir o Brasil porque, antes da anexação do Trono português ao espanhol, em 1580, eles eram os distribuidores dos produtos exóticos portugueses na Europa. Mas, inimigos da Espanha, após 1580, eles foram impedidos de realizar este comércio. Decidiram, então, vir buscar os produtos diretamente no Brasil e, quem sabe, poderiam encontrar um jeito de chegar até o Peru por via terrestre, isto é, às riquezas espanholas. Os holandeses atuavam através de duas Companhias de Comércio: a das Índias Orientais, que explorava o oriente em detrimento dos interesses luso-espanhóis, e a das Índias Ocidentais, fundada, nesta circunstância da União Ibérica, em 1621, para explorar a África, Estados Unidos, Antilhas e Brasil. Para obter diretamente os produtos brasileiros, esta Companhia "invadiu" o território colonial ibérico. Capistrano descreve os avanços e recuos da guerra contra os holandeses à Varnhagen: detalhadamente, com o ritmo de um contemporâneo, de uma testemunha ocular. Entretanto, após 1640, com a separação dos tronos português e espanhol, os holandeses, já instalados em Pernambuco, permaneceram. Começou, então, o irredentismo brasileiro, que exigiu a unificação das forças até então divergentes. Um forte elemento de união foi a fé católica contra o herege. $\mathrm{O}$ catolicismo nativo se exacerbou. $\mathrm{O}$ ataque aos holandeses se fez em nome de Cristo. Índios, 
negros e mestiços diversos participaram vivamente da luta. As vitórias luso-brasileiras se sucederam. Os portugueses que há muito estavam tendo prejuízo no oriente, finalmente "optaram pelo Brasil" e enviaram reforços. Os "patriotas", expressão de Capistrano, aceitaram os reforços portugueses. (p.118)

Para ele, a vitória contra os holandeses só foi portuguesa sob alguns aspectos. Na verdade, entre 1621 e 1654, quando Portugal optava pelo Brasil! e o defendia mais vigorosamente dos ataques estrangeiros, começava a perder o controle sobre o Brasil. Um século e meio depois do seu descobrimento, o Brasil era "redescoberto" por sua nova população. Surgia o "brasileiro", depois de 1654. Esta guerra e esta vitória serviram para revelá-lo a ele mesmo. Havia um sentimento patriótico não português, original, novo, "brasileiro". Vencia o espírito nacional. Reinóis, mazombos, índios, negros, mamelucos, mulatos, curibocas, mestiços de todos os matizes combateram pela liberdade divina. Sob a pressão externa e apoiada na fé católica, operou-se uma solda superficial, imperfeita, mas um princípio de solda entre os diversos elementos étnicos vencedores dos flamengos. Os combatentes de Pernambuco sentiam-se um povo e um povo vencedor, que já possuía os seus próprios heróis. (p.119) Passado o primeiro momento, os reinóis tentarão reassumir a sua atitude de superioridade e proteção. Entretanto, data de meados do século XVII a irreparável e irreprimível separação entre pernambucanos ("brasileiros") e portugueses.

Portanto, se o século XVI terminara com uma tendência à dispersão e à fragmentação, o século XVII terminou com uma tendência não só à integração da população nativa como à formação de uma nação independente. A vitória contra os holandeses foi para os portugueses uma vitória de Pirro: ganharam, mas começaram a perder tudo. Se os portugueses tinham conquistado o litoral, os novos brasileiros conquistarão o sertão. Os portugueses continuaram a viver e a controlar a vida do litoral; os brasileiros adentraram pelo território conquistando-o, ocupando-o, povoando-o. O Capítulos de História Colonial pode ser dividido em duas partes: até às "Guerras Flamengas", capítulo $8^{\circ}$, Capistrano faz uma história do descobrimento do Brasil de tipo Varnhageniano; depois delas, ele passa a fazer um novo tipo de história do Brasil. Não só mudou o sujeito da história do Brasil. Com a mudança do sujeito, mudaram-se os temas, alterouse o objeto e até mesmo a forma da história. Até ali estávamos ainda na velha história político administrativa metropolitana do descobrimento do Brasil. Aqueles dados apresentados e daquela forma já estavam em Varnhagen. A primeira parte dos Capítulos de História Colonial é quase uma síntese de Varnhagen, embora o olhar não fosse mais da caravela sobre o litoral, mas da praia em direção à frota. Esta diferença na direção e posição do olhar, presente na primeira parte liga esta à segunda, impedindo que entre ambas haja uma ruptura. $\mathrm{O}$ que não estava em Varnhagen e marca a originalidade de Capistrano é a sua percepção do surgimento do novo povo e a sua adesão ao seu sentimento e interesse, ao seu projeto político. Tal percepção foi possível porque desde as primeiras páginas do livro, seu olhar já estava em outra posição e direção. As elites saem da história e entra o povo brasileiro, conquistando o sertão, vivendo longe do Rei. O sertanejo é aquele que vive distante do Rei: autônomo, soberano, orgulhoso.

No capítulo $9^{\circ}$, intitulado "O Sertão", Capistrano passa a analisar mais do que a descrever, passa a fazer um esboço de história econômico-social-geográfica-cultural da conquista do Brasil, do seu interior, pelos brasileiros. A ocupação do interior não se deu somente após a vitória contra os holandeses. Ela já vinha se dando desde 1530 com a fundação de Piratininga e com as entradas pelo Tietê em direção ao Prata. A vitória contra os holandeses só revelou nitidamente esta nova identidade nacional. Capistrano irá procurar perceber a sua formação longínqua, muito anterior a este episódio histórico litorâneo, mas de- 
cisivo. Esta vitória foi como uma ponta de iceberg, sinalizou a existência de um mundo histórico invisível, mas que durava desde o século XVI. Capistrano mergulhou perto desta ponta de iceberg e desceu às bases dessa "massa de gelo", para descobrir-lhe o início, a profundidade, a espessura, a densidade. De 1654, a ponta, ele descerá até 1530, a base, quando os paulistas começaram a entrar pelo interior do Brasil (BOSI, 1992).

São Vicente e Piratininga foram um dos pólos de onde partiram os brasileiros para a conquista do sertão. Os bandeirantes iam caçar e escravizar índios. Os paulistas são sobretudo mamelucos e Capistrano vê o povo brasileiro mais como um mestiço de índio e branco. O mestiço de negro e branco é litorâneo e pertence ao mundo português. Ele descreve os ataques bandeirantes aos indígenas e jesuítas e a resistência de uns e outros. Os bandeirantes foram terríveis em suas caçadas. A ação bandeirante já é uma ação da gente brasileira, não é mais uma história portuguesa. As primeiras ações brasileiras se destacaram pela violência e brutalidade contra os indígenas. $\mathrm{O}$ brasileiro continuou a ação colonizadora e cristianizadora do português e usando os mesmos métodos.

D. Ribeiro escreveu recentemente que os bandeirantes ou mamelucos paulistas foram vítimas de duas rejeições básicas. A dos pais, brancos, com quem queriam se identificar, mas que os viam como impuros filhos da terra, dos quais somente aproveitavam o trabalho; e do gentio materno, que não valorizava a descendência materna. Não podendo identificar-se nem com brancos e nem com índios, não tendo ancestrais, portanto, o mameluco cairá na "terra de ninguém", a partir da qual constrói a sua identidade "brasileira". Filho de índia, ele se torna um caçador e escravizador de índios, de sua gente. "Mameluco", esclarece Ribeiro, era o nome dado ao escravo árabe treinado para exercer o mando islâmico sobre a gente de que foram tirados (RIBEIRO, 1995). Filhos de índias, os paulistas agirão contra seus parentes com rara violência, serão "capitães-do-mato", "feitores" de índios. Eles invadirão as missões para prenderem os seus índios. Capistrano não aprecia a história que conta e analisa e se pergunta: compensará tais horrores a consideração de que graças aos bandeirantes pertencem agora ao Brasil as terras por eles devastadas? Eles voltavam a Piratininga com índios prisioneiros amarrados em coleiras uns aos outros. Eram vendidos como escravos. As mulheres índias eram estupradas, conforme o costume. Os jesuítas tentaram de tudo para que eles poupassem os índios. Em vão. Os jesuítas é que foram expulsos. Os bandeirantes eram vistos como "amansadores", "pacificadores" de índios. Circulavam por todo o Brasil levando a guerra ao povo de suas mães. Entretanto, alguns se fixaram e passaram de devastadores a colonizadores do interior do Brasil, vivendo com o que o sertão lhes oferecia.

Outro pólo foi o Maranhão, de onde os brasileiros entraram pela Amazônia, fazendo a mesma devastação do indígena. Fundaram-se engenhos, plantou-se algodão e fumo. Na Amazônia, os brasileiros combateram holandeses, ingleses e franceses. A penetração da Amazônia foi lenta. Era uma região com forte presença de jesuítas, carmelitas e franciscanos. Fundou-se Belém, do Pará. Coletavam os produtos florestais: cravo, canela, cacau, salsa. A Amazônia teve uma prosperidade relativa com a cultura do arroz e do algodão e a introdução de escravos negros. A população crescia lentamente. O Maranhão era, no entanto, muito longe do sul do Brasil e foi preciso criar o Estado do Maranhão, em 1621. A comunicação com o Brasil sul era feita pelo Parnaíba, mas foi preciso também a construção de estradas. Portanto, a partir de Piratininga, os brasileiros desceram até o Prata e subiram até a Bahia, passando por Minas Gerais, foram ao Mato Grosso e Amazônia; a partir do Maranhão, os brasileiros entraram pela Amazônia e desceram pelo sertão nordestino. A conquista do território se fez à custa da expulsão, exterminação e escravização do indígena. Os engenhos de açúcar, o fumo e as roças de mantimentos só vingaram próximo de rios navegáveis. 
Capistrano não aprecia este início da história brasileira, que lhe parece tão violenta quanto a história que os portugueses faziam. Em 1680, ele afirma, a lei portuguesa proibia que os índios fossem escravizados, única solução lógica e justa, se houvesse gente bastante honesta e enérgica para fazê-la respeitada (p.141). Diferentemente de Varnhagen e G. Freyre, que viam os jesuítas como pseudo-filantrópicos, Capistrano se posiciona francamente ao lado deles na proteção ao indígena contra a guerra, contra o seu extermínio e escravidão.

Um terceiro pólo de ocupação do território brasileiro foi a agropecuária. A criação de gado começou em torno de Salvador e ao longo do Rio São Francisco. Aos poucos foi se afastando das margens do rio e adentrando pelos mais profundos sertões da Bahia, Pernambuco, Minas Gerais. Há os "sertões de dentro", baianos, e os "sertões de fora", pernambucanos. Nas vastas regiões interiores dominadas pelo gado, foi também o mameluco que predominou. São regiões impróprias para o cultivo. $\mathrm{O}$ gado prosperou ali, exigindo pouco capital, pouco pessoal, fornecendo alimentos para as regiões exportadoras. O conflito com os índios foi menor, pois o fazendeiro não é nômade e caçador de índios. Desde que estes cedessem suas terras e não comessem do gado, as relações entre eles e os brancos se estabilizavam. Com o gado, caminhos novos foram abertos levando ao mais fundo Brasil. Os brasileiros da pecuária viviam com recursos escassos. Eles só comiam carne, leite, frutas e mel. Faziam tudo de couro: portas, camas, cordas, alforjes, mochilas, roupas, malas... O vaqueiro recebia uma cria em cada quatro crias, depois de quatro a cinco anos de serviço. Podia com o tempo fundar a sua própria fazenda. "Vaqueiro", "homem de fazenda", "criador" são títulos honoríficos entre eles. A fazenda tornouse aos poucos um centro familiar, com grandes e confortáveis casas. Nos caminhos do gado para a cidade, onde era vendido, populações se estabeleceram, povoados surgiam. Esta população distante era também muito católica e, de vez em quando, recebiam padres. Entretanto, viviam entregues a si. O Estado demorou a se instalar com juízes, milícia e administração. $\mathrm{O}$ mundo da pecuária era também um mundo de violências, com bandos de bandoleiros, onde a vingança era comum. Era um mundo de liberdade, sem escravos, semi-povoado, vasto, abundante, familiar e violento.

Além de partir de São Vicente e Piratininga, de São Luís do Maranhão e ocupar o interior da Bahia, Minas, Goiás e o nordeste com o gado, outro pólo de ocupação e povoamento do território brasileiro foram as minas. Foi graças ao gado, por um lado, e à caça do indígena, por outro, que as minas foram descobertas. Não se pretendia achar ouro e pedras preciosas, mas prata, já que esta foi encontrada em Potosi. E o Brasil deveria até ser mais abundante em prata se o "oriente for mais nobre do que o ocidente", como acreditavam que fosse. O ouro foi encontrado sem ser muito procurado. Os paulistas o encontraram, finalmente, no final do XVIII, nas regiões de Minas Gerais e Mato Grosso: Ouro Preto, Mariana, Rio das Mortes, Rio das Velhas, Paracatú e Cuiabá. Os bandeirantes tornaram-se, então, mineiros. Pouco a pouco, tudo era enviado para as Minas, vindo de todas as partes do Brasil e da Europa. Houve uma corrida às minas.

Com os crescimento das minas, uma parte do sertão do Brasil tornou-se português. O Rei voltou a controlar o Brasil. Os tributos aumentaram, a circulação da população foi controlada, a exploração do ouro disciplinada em favor da Coroa. Na Bahia, por estar mais próxima do litoral, a exploração do ouro foi proibida. As minas serão um sertão não brasileiro, não mameluco, mas português, dominado pelo branco e pelo negro e o seu mestiço. Neste sertão mineiro, o domínio português tornou-se tão severo que os sentimentos patrióticos brasileiros se tornaram mais agudos. Os brasileiros, em sua expansão pelo "seu território", já estavam acostumados e tinham gostado de ficarem distantes do Rei. A sua reaproximação foi tão opressiva que desencadeou os movimentos pela independência. 
No final do século XVIII, a solda que une os diversos grupos que compõem a "nação brasileira" se consolidou. A consciência patriótica brasileira se aprofundou. O Rei e sua lei opressora e repressiva serão contestados em diversos pontos do país, exatamente aqueles pontos em que já existia uma população brasileira assentada, com interesses e sentimentos próprios, anti-lusitanos: Maranhão, Pernambuco, Bahia, Minas Gerais, São Paulo. Os triunfos contra os estrangeiros, as proezas dos bandeirantes, a abundância de gado animando os sertões, as minas de ouro e diamantes e outras pedras preciosas, as riquezas remetidas à metrópole, o crescimento da população, afirma Capistrano, influíram sobre a psicologia dos colonos. As descobertas auríferas foram a gota d'àgua, vieram completar a obra. Os brasileiros não se sentiam mais inferiores aos nascidos na metrópole, não eram mais os humildes mazombos do século XVI. Tal mudança, os filhos da metrópole não reconheciam. O reinól é visto, então, como um miserável que vem se enriquecer aqui. Começaram os conflitos entre brasileiros e portugueses. A consciência brasileira formou-se lentamente durante 3 séculos. No final do terceiro século, já era sólida o bastante para ser formulada e expressa e dar legitimidade à ação emancipacionista. Os brasileiros se sentiam sustentadores da Coroa e expoliados por sua opressão.

Em Minas, houve o conflito dos Emboabas (1707/9); em Pernambuco, o conflito dos Mascates (1709/10). Capistrano descreve estes conflitos como se fosse um testemunho ocular. O século XVIII é o século do conflito aberto entre brasileiros e portugueses. Entre as agitações sociais, apareceu um livro que agitará os brasileiros ainda mais ao oferecer-lhes argumentos e força para continuarem em sua luta independentista. Trata-se do livro Cultura e Opulência no Brasil por suas Drogas e Minas, do jesuíta André João Antonil, que o próprio Capistrano descobriu tratar-se do anagrama de João Antôni/o Andre/oni L (luquense), estabelecendo a sua autoria. O livro fala dos engenhos de açúcar, da produção de fumo, das minas e do gado. Ele oferecia os primeiros números sobre o Brasil. Ele foi logo confiscado pela metrópole, pois estaria divulgando para os estrangeiros os segredos do Brasil. Mas, contesta Capistrano, a verdade é outra: o livro ensinava o segredo do Brasil aos brasileiros, mostrando toda a sua pujança, justificando as suas pretensões. Confiscado, proibido, o segredo do Brasil chegou aos brasileiros por outras vias: apareceram exaltações às riquezas do país, exaltações à nobreza brasileira, às suas elites, exaltações do índio como superior aos portugueses e negros, exaltações da natureza, da fauna e flora do Brasil. Por toda parte o segredo do Brasil era revelado. A diferenciação em relação ao reinól, antes gradual, inconsciente e tímida, acelera-se, tornase mais consciente, resoluta e irresistível. A vitória brasileira seria uma questão de tempo.

No $10^{\circ}$ capítulo, Capistrano trata dos limites do território brasileiro. Um "povo novo" precisa de um território bem delimitado. Serão ainda os portugueses que discutirão com os espanhóis e franceses e assinarão tratados instáveis, que serão sempre rediscutidos. Na região do Prata, espanhóis e portugueses trocaram e destrocaram territórios segundo vários tratados. A negociação do território, dos seus limites, foi negociada ainda pelos portugueses. Mas, para defenderem tais territórios, os portugueses tinham um argumento quase sempre irretorquível: já tem "gente brasileira" instalada na Amazônia, no sul e centrooeste, isto é, o território já foi de fato conquistado, ocupado e povoado por "gente brasileira". Os limites já estavam definidos concretamente e os tratados só reconhecerão o povoamento já realizado. Será dentro destes limites, agora legitimados pelo direito, que se instalará o povo brasileiro.

No $11^{\circ}$ capítulo, Capistrano faz um balanço final e tenta uma definição geral do povo brasileiro, do seu estado no final do século XVIII. Aqui, "Três Séculos Depois", é o título do capítulo, Capistrano fará um levantamento e radiografia da população brasileira: 
número, tipos, repartição, caminhos, atividades, alimentações, festas, feiras, roupas, personalidades, costumes, infra-estrutura urbana, relações sociedade/Estado, nível da consciência política. Quanto ao número, a população brasileira já era contada em milhões. Ela se concentrava no litoral e nas margens dos rios que entravam pelo interior. A maioria é mestiça. A mestiçagem variando de região para região. No interior, predominava o mameluco; no litoral e minas, o mulato. Os negros eram maioria no litoral e, apesar das fugas e quilombos, eram em menor número no sertão. No sul, os brancos eram mais numerosos. Capistrano referese às diferentes atividades regionais, às diferentes dietas. Na Amazônia, extraía-se produtos florestais, comia-se peixe e se super-explorava a tartaruga, a "vaca amazônica", o "gado do rio". Na zona pastoril, muita carne e escassez de água, que é salobra, ótima para o gado. Bebia-se garapa, comia-se milho verde. Havia festas sertanejas. Capistrano descreve o vestuário doméstico e domingueiro, a vida das mulheres solteiras e casadas. Nas Minas havia abundância de padres, irmandades; havia o gosto pela música, nas cidades. As festas religiosas eram numerosas e teatrais, luxuosas.

Capistrano compara o caráter dos brasileiros regionais. O mineiro, ele o descreve assim: esbelto, magro, peito estreito, pescoço comprido, rosto alongado, olhos negros e vivos; não se apegam ao seu país, inteligentes, sobrevivem em qualquer ambiente, orgulhoso e afável, brando e cavalheiro. O paulista, assim: pequena estatura, cabelo louro, face pálida, olhos indígenas; corajoso, ágil, incansável, vingativo, franco, colérico e gosta do perigo. Sua cor da pele varia dependendo do grau de mestiçagem indígena/ branco. Ele descreve ainda o baiano, o goiano, o matogrossense, o gaúcho. Sobre as cidades coloniais, ele se refere às portuárias, as mais importantes: São Luís, Recife, Salvador, Rio de Janeiro. Nestas cidades litorâneas, o mulato predominou. Os negros eram numerosos, com sua alegria nativa, seu otimismo per- sistente, sua sensualidade animal!, suportando bem o cativeiro!. Os negros, ele afirma, nunca ameaçaram a ordem de modo sério - trabalhavam cantando, para aliviar o peso do trabalho, e bandos de carregadores negros davam animação às ruas. Os mulatos são mais rebeldes - dentre eles saiam os capangas e assassinos. Crescendo em número, "descoloriram" e extinguiram as distinções de raça. Os brancos eram oprimidos pelo convencionalismo; as crianças, cedo, perdiam toda vivacidade e espontaneidade. Os reinóis tratavam com desdém a terra e os seus moradores; eram grosseiros, desonestos, prepostos dos ingleses.

O $11^{\circ}$ capítulo, portanto, é um balanço quase completo do Brasil no final do século XVIII. Ele fala ainda da arquitetura urbana, dos modos à mesa, do comportamento das mulheres, da vida social (o ritual da "visita"), das ruas e do inexistente saneamento básico ("cuidavam da limpeza urbana o sol, as chuvas e os urubus"!), da indústria cerceada pela metrópole etc. O Brasil não é ainda independente, mas se inquieta a aspira sê-lo. Ele está prestes a tornar-se independente. Entretanto, Capistrano surpreende o leitor no final da sua exaltação da vitória brasileira. Depois de se mostrar entusiasmado com as expressões do sentimento patriótico entre os brasileiros, termina a sua síntese cético em relação ao futuro deste novo povo. Para ele, a vida social não existia, pois não havia sociedade. As questões públicas não interessavam. No máximo se sabia se havia guerra ou paz. É duvidoso que tivessem uma consciência nacional e até mesmo capitanial. Algum leitor de livros estrangeiros poderia falar de independência, porque soube do caso americano e conhecia a pobreza e fraqueza lastimáveis de Portugal. Não se procurava, porém, o meio de conseguir tal independência vagamente conhecida, tão avessa era a índole do povo a questões práticas e concretas. Divagavam sobre o que se faria depois de conquistá-la por um modo qualquer, acontecimentos imprevistos, como afinal aconteceu. Como em todas as revoltas anteriores, não se sabia o que se fa- 
ria com o poder na mão. Enfim, ele conclui, no início do século XIX, a população brasileira era constituída por eram cinco grupos étnicos, ligados pela comunidade ativa da língua e passiva da religião, moldados pelas condições geográficas de cinco regiões diferentes, e tendo pelas riquezas materiais grande entusiasmo - eis a que se reduziu a obra de 3 séculos.

Final paradoxal! Ao longo do texto tem-se o elogio da expansão e conquista do território brasileiro pelos brasileiros. Apesar de ser difícil distinguir os interesses e sentimentos dos brasileiros e portugueses no período colonial, Capistrano esforça-se por definir uma "brasilidade", apesar da dominação portuguesa e contra ela. "Brasilidade" que começa com a fundação de São Vicente e Piratininga, que cresceu com as bandeiras, com a ocupação da Amazônia, com o gado e as minas. "Brasilidade" que se exaltou durante o século XVIII e se expressou através de rebeliões diversas, sangrentas. "Brasilidade" de uma população numerosa, mestiça, com os seus modos próprios de viver e pensar, com as suas atividades econômicas específicas, adaptadas a regiões diversas. Apareceu até um livro que formulava precocemente esta "brasilidade" e que foi apreendido por esta razão. E, no final, um ar de decepção, de malogro: patriotas incapazes de produzir a sua própria independência! É como se a conclusão que ele apresentara para o século XVI - um Brasil dominado por forças centrífugas, divergentes - valesse também para o final do XVIII. Capistrano talvez esperasse mais desse povo que soube acompanhar ao longo de 3 séculos; que ele fosse sujeito de fato da sua autonomia, que ele fosse um sujeito historicamente eficaz. O final revela uma expectativa não realizada, um esforço frustrado, a "revolução brasileira" não passou de um espírito e que não se encarnou, não deu nascimento a um novo mundo histórico. Capistrano passa do elogio à vitória brasileira a um tom crítico em relação ao novo povo brasileiro que se constituía - ele esperava mais ação, mais vontade e determinação, mais eficácia histórica.
Capistrano expressará melhor este seu ponto de vista em um outro texto, Os Caminhos Antigos e o Povoamento do Brasil. Ali, ele constata e pergunta: no princípio do século XIX, o Brasil já estava ligado por meio de vias terrestres e fluviais - chegou-se a formar um conjunto, uma nacionalidade? Para ele, o sistema colonial produzia a divergência interna, o particularismo. O centro ficava além-mar. Somente depois da Independência é que começou o processo de unificação, a convergência das partes. Apesar das mudanças realizadas, este processo se deu naturalmente, em uma evolução gradual, lentamente. Após a Independência, a nação ficou tão cimentada em sua união que desafiou as crises da Regência e se consolidou ainda mais no Segundo Reinado. A idéia de uma nação brasileira realizou-se, finalmente, mas ela esteve perto de esvair-se como em um sonho!

Seu final paradoxal é, no entanto, lúcido: os brasileiros, e pelas razões por ele apontadas, não se sentiam em condições de assumir o país plenamente, isto é, revolucionariamente. Eles viveram os três séculos coloniais na dispersão, em muitos engenhos, minas, fazendas, cada um destes núcleos econômico-sociaisculturais com sua própria lei e seu próprio senhor. Entretanto, esta idéia da "revolução brasileira", que Capistrano concebeu e descreveu no período colonial, quando nascia, será tematizada por todos os historiadores posteriores a Capistrano, que se inserem na linha aberta por ele da "redescoberta do Brasil". Poderia ter sido acelerado o tempo histórico do Brasil, pelos brasileiros, no final do século XVIII, produzindo uma verdadeira independência econômico-socialmental, além de política? Seu ceticismo revela a compreensão dessa impossibilidade histórica. É um sentimento posterior à exaltação que se frustrou: uma recusa apaixonada, decepcionada, do sonho. E depois, uma constatação do que de fato ocorreu, a vinda da Corte para dentro e a consolidação da unidade brasileira em termos "luso-brasileiros", aceitando-a e legitimando-a. Era esta a única revolução independentista 
possível? Pelo menos esta, felizmente, se realizou e a nação brasileira se concretizou antes de esvair-se em um sonho. Seu sentimento parece ter passado por três fases: $1^{\circ}$ ) o elogio da rebelião, da luta e da vitória brasileira durante três séculos; $2^{\circ}$ ) decepção e frustração com a não concretização do que parecia maduro, a Independência feita pelos patriotas brasileiros; $3^{\circ}$ ) a aceitação e legitimação da "Independência possível”, liderada pelo Estado português, pela Família Real Portuguesa, pois, assim, pelo menos, a unidade territorial e nacional foi preservada.

Capistrano é, enfim, um anti-varnhageniano. Nos anos 1900, a história que se faz no Brasil começa a diferenciar-se dos "quadros de ferro" do IHGB e de Varnhagen. Capistrano ainda não faz uma história plenamente econômico-social-mental, mas não faz também mais somente uma história político-administrativa e biográfica. Para A. Canabrava, ele se coloca entre duas concepções de história: a história como narrativa do empírico, que tem em Varnhagen seu representante maior, e a história no quadro das ciências sociais, que se fará no Brasil pós-1930. Capistrano representaria um elo entre a geração do século XIX/IHGB e a geração do século XX/Universidades (CANABRAVA, 1971).

Capistrano se aproxima ainda de Varnhagen nos seguintes pontos: faz ainda uma história factual, relatando os feitos dos portugueses em sua conquista, uma história cheia de nomes e datas, de eventos contados em um ritmo quase diário. Isto vale sobretudo para os primeiros capítulos de Capítulos de História Colonial. Ele dá ênfase à documentação escrita e bem criticada e seu estilo é ainda descritivo e narrativo.

Mas, diferencia-se enormemente de Varnhagen: não faz mais uma história oficial, ligada ao Estado; sua história não é só político-administrativa, mas também social e cultural. E a diferença maior: não faz um elogio da conquista e da colonização portuguesa, mas da conquista e colonização do Brasil pelo brasileiro mestiço; não relata a conquista do litoral, mas a ocupação do interior; o sujeito da história do Brasil não é mais o europeu branco, cristão e súdito do Rei, mas o brasileiro mestiço, ainda cristão, mas sem uma expressão política clara; não faz uma história da constituição da identidade brasileira em moldes europeus, mas busca as identidades brasileiras no interior, no sertão e nas rebeliões. Finalmente, o abismo que os separa está na concepção do tempo histórico do Brasil. Varnhagen não distinguiu bem os períodos da história brasileira e se perdeu em inúmeros fatos dominados pelo sentido maior do elogio da colonização portuguesa. Este sentido maior nunca foi seriamente contestado e Varnhagen não percebeu as "mudanças" na história do Brasil. Capistrano elaborou a seguinte periodização da história do Brasil:

1500-1614 - ocupação do litoral, guerra contra os franceses, escravização do indígena;

1614-1700 - o litoral povoado, começa a internalização pelos rios;

1700-1750 - dominam as minas;

1750-1808 - consolidação do sistema colonial: municipalidades anuladas, indústria proibida, jesuítas expulsos, tensão entre colonos e reinóis;

1808-1850 - decomposição do sistema colonial;

1850 - período centralizador, imperialista ou industrial: época do vapor, a escravidão agoniza, jornalismo vivo. (CAPISTRANO, 1975)

Diferente de Varnhagen, Capistrano duvida da tradição, faz uma crítica radical da memória. A verdade que procura não consiste na repetição do passado: a verdade não é o que o passado ensina e obriga. (ARAÚJO, 1988) Seu ponto de vista inovador, ao mesmo tempo constrói um novo passado e desconfia do passado estabelecido, oficial. O método crítico quer corrigir o passado, rever verdades consolidadas. E abrir um novo futuro, sustentado por um novo passado: o Brasil nação não será oficial, o sujeito da história do Brasil não é o Estado Imperial, mas o "povo brasileiro", em sua diversidade e unidade. No passado, Capistrano põe ênfase na vida 
desse povo, por um lado, ativo na ocupação do território, por outro, passivo e ineficaz na produção da verdadeira independência; no futuro, ele espera a verdadeira Independência... Capistrano é um historiador da mudança, da descontinuidade entre o passado e o futuro do Brasil: o futuro será a realiza-

\section{Bibliografia}

ARAÚJO, R.B. "Ronda Noturna: Narrativa, Crítica e Verdade em Capistrano de Abreu". Estudos Históricos, Rio de Janeiro, Vértice, n. 1, p.28-54, 1988.

BOSI, A. "O Tempo e os Tempos", in NOVAES, A. (Org.) Tempo e História. São Paulo, Cia das Letras/Secretaria Municipal de Cultura, 1992, p.19-32.

CÂMARA, J.S. Capistrano de Abreu. Rio de Janeiro, José Olympio, 1969 (Col. Documentos Brasileiros), 234p.

CAMPOS, P.M. "Esboço da Historiografia Brasileira nos Séculos XIX e XX", in GLENISSON, J. Iniciação aos Estudos Históricos. São Paulo, Difel, 1983, p.250-293.

CANABRAVA, A. "Apontamentos sobre Varnhagen e Capistrano". Revista de História. São Paulo, USP, v. XVIII, n. 88 , out/dez.1971. p.417-424.

CAPISTRANO DE ABREU, João. Capítulos de História Colonial (1500-1800) \& Os Caminhos Antigos e o Povoamento ção da independência que no passado o Brasil aspirou mas não realizou. $\mathrm{O}$ futuro do Brasil será brasileiro, descontinuando o passado português. A verdade histórica se oporá a este passado tradicional português e servirá à construção do futuro novo, "brasileiro", à idéia da "revolução brasileira".

do Brasil. 5a. ed. Brasília, UnB, 1963, 337p. (1ª ed. 1907).

CHACON, V. História das Idéias Sociológicas no Brasil. São Paulo, Ed.USP/Grijalbo, 1977, 139p. Gilberto Freyre, uma biografia intelectual. Recife/São Paulo: FUNDAJ/Ed.Massangana/Ed.Nacional, 1993, 312p.

ODÁLIA, N. "Formas do pensamento historiográfico brasileiro". Anais de História, Assis (SP): UNESP, 1976, n. 8, p. 31-40.

REIS, J.C. A História Metódica, dita "Positivista". A História, entre a Filosofia e a Ciência. São Paulo, Ática, 1996, p.11-25.

RODRIGUES, J.H. "Introdução". Capítulos de História Colonial (1500/1800) \& Os Caminhos Antigos e o Povoamento do Brasil. 5a. ed. Brasília, UnB, 1963, p.IX-XIX e 3-28.

"Capistrano de Abreu e a Historiografia Brasileira". História e Historiadores do Brasil. São Paulo, Fulgor, 1965, p.34-53.

WEHLING, A. A Invenção da História. Rio de Janeiro/ Niterói:Gama Filho/UFF, 1994, 260p. 